\title{
CONF-800231-. 3
}

THE EFFECT OF ADVECTION ON VARIATIONS IN ZOOPLANKTON AT A SINGLE LOCATION NEAR CABO NAZCA, PERU

S.L. Smith, K.H. Brink, H. Santander, T.J. Cowles, and A. Huyer

APRIL 1980

Prepared for Presentation at

The International Symposium on Coastal Upwelling

Los Angeles, California

February 4-8, 1980

OCEANOGRAPHIC SCIENCES DIVISION

DEPARTMENT OF ENERGY AND ENVIRONMENT

BROOKHAVEN NATIONAL LABORATORY

UPTON, NEW YORK 11973 


\section{DISCLAIMER}

This report was prepared as an account of work sponsored by an agency of the United States Government. Neither the United States Government nor any agency Thereof, nor any of their employees, makes any warranty, express or implied, or assumes any legal liability or responsibility for the accuracy, completeness, or usefulness of any information, apparatus, product, or process disclosed, or represents that its use would not infringe privately owned rights. Reference herein to any specific commercial product, process, or service by trade name, trademark, manufacturer, or otherwise does not necessarily constitute or imply its endorsement, recommendation, or favoring by the United States Government or any agency thereof. The views and opinions of authors expressed herein do not necessarily state or reflect those of the United States Government or any agency thereof. 


\section{DISCLAIMER}

Portions of this document may be illegible in electronic image products. Images are produced from the best available original document. 
- DISCLAIMER

This book was prepared as an account of work sconsored by an agency of tha United States Government. Neither the United Stares Government nor any agency thereof. nor any of their employees, makes any

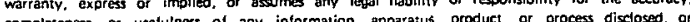

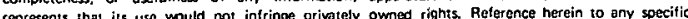
commercial oroduct, process or sevice by trade name, trademark, manufocturer, or otherwise, coes not necesesgily constivute or imply its endorsement, recommendation. or favoring by the Unites States Government or any agency thereod, The views and opinians of authors expressed herein do not necessarily stare or reflect those of the Unired States Government or any agency thereot.

THE EFFECT OF ADVECTION ON VARIATIONS IN ZOOPLANKTON AT A SINGLE LOCATION NEAR CABO NAZCA, PERU

S.L. Smith, 1 K.H. Brink, ${ }^{2}$ H. Santander, 3 T.J. Cowles, ${ }^{4}$ and A. Huyer ${ }^{2}$

APRIL 1980

${ }^{1}$ Brookhaven National Laboratory Upton, New York 11973

${ }^{2}$ School of Oceanography Oregon State University Corvallis, Oregon 97331

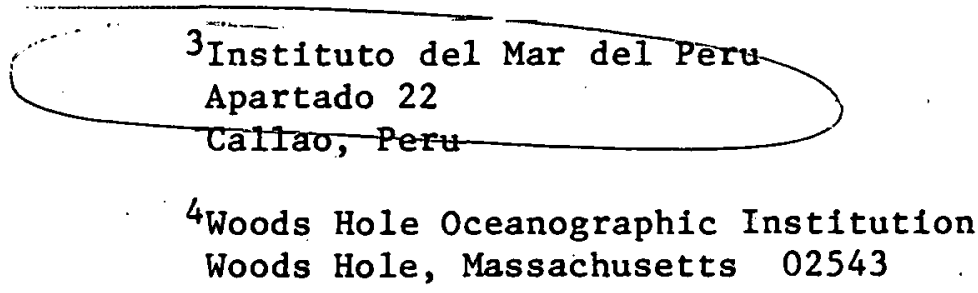

Prepared for Presentation at The International Symposium on Coastal Upwelling

Los Angeles, California February 4-8, 1980

Research supported by a grant by the Coastal Upwelling Ecosystems Analysis (CUEA) Program of the Office of the International Decade of Ocean Exploration (IDOE) of the National Science Foundation and the Instituto del Mar del Peru. 


\section{ABSTRACT}

Temporal variations in the biomass and species composition of zooplankton at a single midshelf station in an upwelling area off Peru can be explained to a large extent by onshore-offshore advection in the upper $20 \mathrm{~m}$ of the water column. During periods of strong or sustained near-surface onshore flow, peaks in biomass of zooplankton were observed at midshelf and typically oceanic species of copepod were collected. In periods of offshore flow at the surface, a copepod capable of migrating into oxygen-depleted layers deeper than $30 \mathrm{~m}$ was collected. A simple translocation model of advection applied to the cross-shelf distribution of Paracalanus parvus suggests that the fluctuations in $\underline{P}$. parvus observed in the midshelf timeseries were closely related to onshore-offshore flow in the upper $20 \mathrm{~m}$.

Fluctuations in abundance of the numerically dominant copepod, Acartia tonsa, were apparently affected by near surface flow also. The population age-structure suggests that $\underline{A}$. tonsa was growing at maximal rates, due in part to its positive feeding response to the dinoflagellate/diatom assemblage of phytoplankton. 


\section{INTRODUCTION}

Temporal variations in zooplankton at a given location in an upwelling region can occur as a result of both biological and physical processes. Biologically, variations occur on a time scale of weeks associated with the life cycle of the organisms, and on a diurnal time scale associated with vertical migration. Physically, variations may occur as a result of onshore-offshore and alongshore advection which generally have a dominant time-scale of several days, intermediate to the two dominant biological time scales. We shall examine the temporal variability of zooplankton observed during a 15-day period of daily observations at a single location in the coastal upwelling region off Peru.

The observations of zooplankton were obtained from vertical net hauls made primarily at a single midshelf location, called $\mathrm{C}-3$; ; about $15^{\circ} 07^{\prime} \mathrm{S}$, $75^{\circ} 31^{\prime} \mathrm{W}$ over the shelf just south of Cabo Nazca (Figure 1). These net hauls were made from R. V. Alpha Helix daily from 28 March to 11 April 1976, at about the same time each morning, between 0900 and $1100 \mathrm{LST}$, to avoid possible aliasing from the diurnal cycle of vertical migration. Live specimens of the dominant species, Acartia tonsa, were collected from the net hauls and maintained in the laboratory to study their grazing habits. The offshore distributions of zooplankton were inferred from occasional observations between April 1 and April 5 at other locations along the C-line (Figure 1). No direct information is available about the alongshore distribution of zooplankton, but alongshore variation in biological variables are believed to be much less than offshore variations (Dugdale et al., 1977). Our observations have been made during an atypical period in the upwelling regime off Peru. Dinoflagellates dominated the phytoplankton along much of 
the coast (Dugdale et al., 1977; Rojas de Mendiola, 1979), and denitrification was taking place (Packard et al., 1978). The prevailing conditions in 1976 have been characterized both as an aguaje (Rojas de Mendiola, 1979) and an El Niño (Wyrtki, 1977).

Observations on currents were made during this period at two locations over the shelf: at Mila, alongside $\mathrm{C}-3$, and at Agave, inshore of $\mathrm{C}-3$ (Figure 1). The current meters at Mila were all at depths greater than 25 $\mathrm{m}$, but at Agave one of the current meters was at $10 \mathrm{~m}$, which is usually well within the surface Ekman-like layer. Wind observations were made at a coastal station at San Juan (Figure 1). Preliminary analysis indicated that the zooplankton data were not correlated with either the alongshore wind or the alongshore currents at Mila or Agave. However, the onshore component of the near-surface current seemed to account for some of the variability in the zooplankton samples. Some of the variability, particularly in the dominant species Acartia tonsa and hence in the biomass, can also be explained in terms of in situ growth. We shall demonstrate that onshore-offshore advection alone accounts for the occurrence of most of the species of zooplankton at $\mathrm{C}-3$, while both growth and advection affect the occurrence of the dominant species, Acartia tonsa.

\section{METHODS}

Zooplankton were collected in vertical hauls of $60 \mathrm{~cm}$ diameter "Bongo" frames fitted with 102 m mesh nets (S. Smith, 1978) and in vertical hauls of $70 \mathrm{~cm}$ diameter Hensen net fitted with a $300 \mu \mathrm{m}$ mesh net and a $10 \mathrm{~mm}$ mesh prefilter in the net mouth. At stations with depths less than $100 \mathrm{~m}$, hauls of the Hensen net were from bottom to surface and 50 m to surface, while at deeper stations two hauls were from $200 \mathrm{~m}$ to surface and one was from $50 \mathrm{~m}$ 
to surface. One of the deeper hauls at each station was frozen and returned to the laboratory where it.was washed with distilled water onto a preweighed filter, dried at $60^{\circ} \mathrm{C}$ for $48 \mathrm{~h}$, and weighed. All other samples were preserved in formalin for determination of displacement volume and the quantitative analysis of species composition. The hauls of the "Bongo" nets were from $100 \mathrm{~m}$ or $200 \mathrm{~m}$ to surface depending on station depth. The collection from one net was poured through sieves of 102, 223, 505, and $1050 \mu \mathrm{m}$ mesh, dried at $60^{\circ} \mathrm{C}$, weighed and corrected for phytoplankton (see S. Smith, 1979, for details). Net hauls at $\mathrm{C}-3$ and $\mathrm{C}-5$ were taken during daylight in order to remove the effects of diurnal migration.

Grazing rates of Acartia tonsa were measured in late April 1976. Adult $\underline{\text { A. }}$ tonsa were sorted from samples collected by vertical net tows ( 1 $100 \mathrm{~m}$ ) into beakers containing unfiltered surface seawater. Experimental. food conditions were established from ambient chlorophyll a concentrations at selected euphotic zone depths. Ambient concentrations were occasionally diluted with filtered seawater to create a range of food concentrations. Two adult $\underline{A}$. tonsa were placed into $250 \mathrm{ml}$ experimental bottles, each experiment having at least two replicates plus a control. Bottles were held in a light-tight water bath for 24 hours. Surface sea water circulated through the bath, keeping temperatures within $1^{\circ} \mathrm{C}$ of "catch" temperatures, and also gently rolling the polyethylene bottles such that the particulate food remained in suspension. Since a Coulter counter was not available on this cruise, grazing rates have been calculated based on initial and final chlorophyll a concentrations in the control and experimental bottles. The equations of Frost (1972) were used to calculate rates. Data are presented in terms of carbon, assuming a carbon chlorophyll ratio of 50 (see Cowles, 1977, for details). 
The current and temperature observations were obtained from Aanderaa current meters on subsurface moorings with instruments at 10 and $29 \mathrm{~m}$ at Agave, at 28, 53, and $78 \mathrm{~m}$ at Mila, and with additional instruments at more distant locations. The time-series were low-pass filtered with a half-power point of 47 hours to remove tidal and other variations of shorter period. Details of installation and data treatment can be found in Enfield, Smith, and Huyer (1978), and data are discussed more fully in Brink, Allen and R. Smith (1978) and R. Smith (1978). The San Juan wind data were obtained from a land-mounted anemometer with good exposure to the coastal winds (Stuart et a1., 1976).

\section{RESULTS}

The Flow Field

The mean currents (Table 1) for 39.5 days from 28 March to 6 May 1976, including the period of daily observations of zooplankton show that the flow is equatorward and weakly offshore near the surface at Agave, and poleward and onshore at each of the deeper current meters at both locations. The equatorward flow at 10 in Agave is part of the wind-driven surface current, while the poleward flow elsewhere is part of the undercurrent (Brink, Allen and Smith, 1978). The mean onshore flow at depth and offshore flow at the surface are consistent with an upwelling circulation pattern driven by the mean equatorward alongshore wind stress of 0.82 dynes $\mathrm{cm}^{-2}$. The mean flow at $10 \mathrm{~m}$ Agave is probably representative of the mean near-surface currents across the whole shelf in this region. Direct observations of both near-surface and subsurface currents with better vertical resolution at nearby locations in 1977 (Brink, Smith and Halpern, 1978) substantiate this conclusion. 
Fluctuations in the currents in this region are associated with fluctuations in the local wind stress and with remotely generated disturbances that appear to propagate as low frequency, coastally trapped waves (R. Smith, 1978). At both Agave and Mila, fluctuations in the alongshore current are not significantly correlated with the local wind stress (Brink, Allen and R. Smith, 1978). The alongshore current fluctuations at all. current meters are significantly correlated with each other, and with current observations off Callao (375 km north of Mila and Agave) but with a lag of 2 days due to the wave propagation (R. Smith, 1978). Fluctuations in the onshore flow at the deeper current meters are significantly but weakly correlated with the alongshore wind stress, with stronger onshore flow when the equatorward wind stress is stronger. Simple Ekman dynamics would lead us to expect that the surface offshore flow is also stronger when the wind stress is stronger, but the onshore component of the current at $10 \mathrm{~m} \mathrm{Agave}$ is not significantly correlated with the local wind stress (Brink, Allen and Smith, 1978). Part of the variance in the onshore flow might be due to propagating disturbances. In either process, variations in the onshore current at 10 m Agave are probably representative of the near-surface flow across the whole shelf in this region.

\section{B1omass of Zooplankton}

Net hauls at $C-3$ were made from both $50 \mathrm{~m}$ and $100 \mathrm{~m}$ with the $300 \mathrm{~m}$ Hensen net. The time-series of settled volume from both hauls (Figure 2) shows that they captured similar amounts of zooplankton. On 2 and 8 April, jellyfish fragments were abundant; these probably account for the higher volume from $50 \mathrm{~m}$ than $100 \mathrm{~m}$ on April 8. Except on 28 March and 1 April, when the $100 \mathrm{~m}$ haul had significantly greater volume than the $50 \mathrm{~m}$ haul, the zooplankton at $\mathrm{C}-3$ were concentrated in the upper $50 \mathrm{~m}$. 
The concentration of the zooplankton within the upper $50 \mathrm{~m}$ may be due in part to the presence of water with very low oxygen concentrations. The vertical profile (Figure 3 ) of dissolved oxygen data collected during this period (MacIsaac et al., 1979) shows values less than $1 \mathrm{ml}^{\cdot 1^{-1}}$ at depths greater than $30 \mathrm{~m}$. These values may be overestimates, since this water showed evidence of denitrification (Packard et al, , 1978). If most species of zooplankton avoid this oxygen-depleted water, and there is evidence that some do (Boyd et al., 1980) most of them would be concentrated in the upper $30 \mathrm{~m}$. Furthermore, the surface mixed layer was less than $15 \mathrm{~m}$ throughout this study (MacIsaac et al., 1979). If such near-surface concentration occurred, we would expect the near-surface currents, represented by $10 \mathrm{~m}$ Agave, to have a significant effect on the distribution of zooplankton. Time-series of the biomass of zooplankton at C-3 (Figure 2) were obtained from the $100 \mathrm{~m}$ hauls of each net; estimates from the $300 \mu \mathrm{m}$ Hensen net are smaller by about a factor of five than those from the $102 \mu \mathrm{m}$ Bongo net, indicating that much of the biomass is made up of zooplankton smaller than $300 \mu \mathrm{m}$. Dry weights from two size fractions collected in the $102 \mu \mathrm{m}$ Bongo net (Figure 4) also show that over the shelf most of the biomass of zooplankton is in the smaller $(<505 \mu \mathrm{m})$ size category. Variations in the two biomass estimates are qualitatively similar, except for a large discrepancy on April 5, for which the Bongo net estimate is questionable. Comparing day-to-day fluctuations in biomass with the cross-shelf flow measured at $10 \mathrm{~m}$ Agave shows that peaks in biomass generally occurred during onshore flow and that biomass was least during offshore flow (Figure 2). The largest biomass appeared near the end of the period of sustained onshore flow between 2 and 6 April (Figure 2). 
The qualitative similarity between biomass and the onshore flow can be explained by the offshore distribution of zooplankton biomass: For each size range, the biomass increases near the shelf break (Figure 4). The total biomass of zooplankton smaller than $505 \mathrm{~m}$ has a maximum at the shelf edge, with lower biomass farther offshore. As an additional comparison between the cross-shelf flow and the biomass, we computed a "predicted" time-series by assuming that the offshore profile of Figure 4 is representative for a particular date, and that this profile is passively displaced onshore or offshore without distortion. We assumed the offshore profile of total biomass (both $>102 \mu \mathrm{m}$ and $>300 \mu \mathrm{m}$ ) was representative for 3 April, the date on which the net hauls at $\mathrm{C}-5$ shelf break were made. The displacement for each date before and after 3 April was computed from the time integral of the cross-shelf current at $10 \mathrm{~m}$ Agave. The resulting time-series of "predicted" biomass (Figure 5) does not agree very well with the observed biomass, but it does pick up the two major peaks in biomass that occurred on 31 March and 4-6 April. We repeated the calculation of "predicted" biomass using crossshelf currents averaged over several depths but all other combinations failed to pick up the March 31 peak in biomass. We also used the offshore profiles of biomass for different size fractions, but found no improvement in the "predicted" biomass. Although agreement is n'bt good, the coincidence of peaks for the two different series of net hauls suggests that the zooplanktonic community as a whole was sensitive to currents in the uppermost part of the water column. The implication is that for the most part zooplankton were restricted to the layer influenced by surface currents. Any agreement is encouraging since there was bound to be distortion in the pattern, the cross-shelf profile (Figure 4) was not synoptic, and in situ processes were ignored. 


\section{Species Composition}

Patterns of the abundance and diversity show three groups of copepod species associated with the continental shelf, continental slope, and deep ocean. The shelf group, composed of Acartia tonsa Dana and Centropages brachiatus Dana, decreased sharply in abundance offshore of the shelf break (Figure 6). The continental slope group, containing Paracalanus parvus Claus, Eucalanus spp. and Oncaea spp., increased gradually in abundance from midshelf to $110 \mathrm{~km}$ offshore (Figure 6). The deep water or oceanic group contalned seventeen species which were abundant between 80 and $110 \mathrm{~km}$ offshore; four are shown in Figure 6.

Day-to-day fluctuations in the abundances of each group of species at C-3 (Figure 7) show the effects of onshore-offshore advection more clearly than does biomass. The numerically dominant copepod during this study was Acartia tonsa, a cosmopolitan and opportunistic species often found associated with dinoflagellate blooms (Conover, 1956; Seki et al., 1974; S. Smith, 1978; Morey-Gaines, 1979; Walsh et al., 1974). This species is regularly present in coastal waters off' northern Chile (Vidal, 1968) and off Peru (Heinrich, 1973), but it is not abundant in normal oceanographic periods (Hcinrich, 1973). The maxlmum abunaance of A. tonsa occurred during the period of sustained onshore flow (2-6 April) with a secondary peak during the relatively brief but strong onshore flow of 30-31 March (Figure 7). Lowest numbers were associated with periods of offshore flow. The next most abundant species, the shelf copepod Centropages brachiatus, also had maxima during periods of onshore flow (Figure 7), suggesting that shelf species accumulate at C-3, and probably inshore of $\mathrm{C}-3$ during onshore flow.' 
Two of the slope species, Paracalanus parvus and Oncaea spp., also have peak abundances during periods of onshore flow; during the period of sustained onshore flow (3-6 April) they lag the shelf species by a day. The oceanic species do not appear during or after the short burst of strong onshore flow on 31 March, but they were observed during and immediately after the period of sustained onshore flow (Figure 7). In addition, other organisms such as Euphausia mucronata (Euphausiacea), Muggiaea atlantica (Siphonophora) and doliolids which generally occur seaward of the shelf break were captured at C-3 during periods of onshore flow. Figure 7 suggests a lag in abundances of the three groups following onshore flow beginning on 3 April: Acartia tonsa peaks on 4 April, the slope species' peak on 5 April, and the oceanic species peak on 6 April.

One of the species in the continental slope group, Eucalanus inermis. Giesbrecht, was most abundant at $\mathrm{C}-3$ on 2 April, in a period of offshore flow at Agave $10 \mathrm{~m}$ (Figure 7). This species was not confined to the upper layer $(<30 \mathrm{~m})$ over the shelf in this area in 1977 (Boyd et al., 1980): It had the ability to migrate deeper than $30 \mathrm{~m}$ where oxygen concentrations were generally less than $0.1 \mathrm{ml} \cdot 1^{-1}$. Thus Eucalanus inermis was probably not restricted to the near-surface layer and is likely indicative of freshly upwelled water being advected offshore.

Since there was a cross-shelf pattern in the species of zooplankton, we computed "predicted" abundances from the offshore abundance profile and the onshore current data, in the same way as we computed "predicted" biomass described above. In particular, we computed the "predicted" abundance of Paracalanus parvus, one member of the continental slope group of species. We assumed that the offshore distribution of $\underline{P}$. parvus shown in Figure 6 was 
valid for 3 April; its onshore or offshore displacement from this date was determined from the time-integral of the cross-shelf current at $10 \mathrm{~m}$ Agave (other estimates of the cross-shelf current were also used, but the $10 \mathrm{~m}$ Agave data again gave the best prediction). The overall agreement of the observed and "predicted" curves (Figure 8) is startling considering how simplistic the calculation is: ignoring the effect of the nearby coast, assuming onshore currents are the same in all space, neglecting alongshore effects and assuming that zooplankton are conservative, passive irarers. We conclude that advective effects are extremely important in determining the distribution of Paracalanus parvus, and that since shallow currents give by far the best prediction, its population is concentrated in the upper 10-20 m of the water column. The second conclusion is supported by the observation that generally 0-50 $\mathrm{m}$ and $0-100 \mathrm{~m}$ casts show similar patterns in Paracalanus parvus counts. On 7 and 8 April large numbers of $\underline{p}$. parvus were collected below $50 \mathrm{~m}$ while few were collected above $50 \mathrm{~m}$, resulting in an over prediction of the Paracalanus parvus population. Similar calculations for Centropages brachiatus and Acartia tonsa show general agreement between observed and predicted abundances at $\mathrm{C}-3$ as well (Figure 8 ) though both patterns have ovor predictione on 38 and 29 March and 7 and 8 April. The uvel predlellun on 7 and 8 April suggests that on those days much of the zooplanktonic community may have been distributed deeper in the water column than on other days of the time-series.

\section{The dominant species: Acartia tonsa}

Until this point we have been presenting evidence that mass and species composition of zooplankton passing our fixed point $(C-3)$ on the continental shelf off Peru in 1976 were associated with the onshore flow measured at 10

$$
-10-
$$


m depth nearshore. That advection was not the only factor determining the abundance of zooplankton at $\mathrm{C}-3$ becomes clear when we consider the biological characteristics of $\underline{A}$. tonsa, the numerically dominant copepod during this study (Figure 7).' Analysis of daily collections with the $102 \mathrm{~m}$ mesh nets from $\mathrm{C}-3$ for the percent composition of nauplii and copepodids show three peaks in copepodid proportions and two in the proportion of nauplii (Figure 9). Using the laboratory data of Heinle (1966) and the sea-surface temperatures prevailing during this time-series, a maximal growth rate of Acartia tonsa could produce an egg-to-egg cycle of 11 to 13 days with the age-structure shown in Figure 9. Comparing the age-structure of an A. tonsa population resulting from the maximum growth rate calculated from laboratory data with the observed population age-structure suggests that most of the observed proportions of nauplii and copepodids in the A. tonsa population could result from the introduction of new nauplii and copepodids on two different days followed by maximum growth (Figure 9). The days on which new nauplif would have to have been advected into the $\mathrm{C}-3$ area are 27 March and 4 April 1976, days which are near the end of periods of onshore flow.

The ingestion rate of Acartia tonsa increased linearly with food concentrations (Figure 10). The ingestion experiments were done over a period. of 7 days (22-28 April 1976) when the composition of phytoplankton was changing from about $50 \%$ diatoms to about $85 \%$ diatoms (Blasco, personal communication). Comparison of the results in Figure 10 with phytoplankton composition data indicate that shifts in the relative abundance of diatoms and dinoflagelates had little or no effect on the measured ingestion rate of A. tonsa. The phytoplankton were dominated by diatoms and/or Gymnodinium splendens throughout March and April 1976 (Blasco, personnal communication), 
and mean chlorophyll a for the euphotic zone between 28 March and 11 April 1976 ranged from $2.5 \mathrm{mg}^{\cdot} \mathrm{m}^{-3}$ to $50.5 \mathrm{mg}^{\cdot \mathrm{m}^{-3}}$ (MacIsaac et a1., 1979), indicating that adequate plant food was available throughout the timeseries. Since food for Acartia tonsa was abundant and of appropriate size (Morey-Gaines, 1979), and our estimates of the dates of new introductions of nauplii have a reasonable foundation, we conclude that advection and a potentially maximal growth rate operate together to create the large numbers of Acartia tonsa observed.

\section{DISCUSSİ̃oN}

Previous studies of advection and zooplankton in areas of upwelling have not demonstrated explicitly the relationship of daily fluctuations in the cross-shelf patterns in species of zooplankton and onshore-offshore advection (Longhurst, 1967; Peterson et al., 1979). The combination of current meters moored at midshelf and nearshore at $15^{\circ} \mathrm{S}$, cross-shelf sampling of zooplankton, and daily biological measurements of the entire midshelf water column have allowed us to demonstrate that the species composition and biomass of zooplankton at nidshelf were closely related on a daily basis to onshore-offshore displarement of roughly the upper $20 \mathrm{~m}$ of the wirler column. We have been able to separate short-term advective effects on the zooplankton at midshelf and to separate that effect from the effect of in situ growth by the numerically dominant copepod in the area. The considerable variability on short time-scales (daily) observed during this study in the Peruvian upwelling system suggests that studies of seasonal means, such as that of Peterson et al. (1979), neglect a time-scale which may be important in understanding the dynamics of upwelling systems.

We did not observe any effects that we can attribute to alongshore flow, although the alongshore current is much stronger than the cross-shelf 
current over, the Peruvian shelf (Brink, Allen and Smith, 1978). At Mila, adjacent $\mathrm{C}-3$, the alongshore flow is stronger than the cross-shelf flow by a -factor of at least three for the mean, and a factor of two for the standard deviation. Nearer shore, at Agave, the differences are even greater: A factor of four or more for the means, and a factor of three for the standard deviations. If alongshore gradients were weaker than offshore gradients by a factor of two or three, alongshore currents still would have, about as great an effect in producing local results at $\mathrm{C}-3$ as cross-shelf currents, since the advective effect due to a component is proportional to velocity times the gradient in the given direction. Because our results can be explained by cross-shelf currents and cross-shelf biological profiles, we conclude that the alongshore gradients are even weaker. The presence of the dinoflagellate Gymnodinium splendens along the entire coast of Peru during this period (Rojas de Mendiola, 1979; Dugdale et al., 1977) also suggests that alongshore biological gradients were weak:

We would not expect our results to be found in regions where alongshore gradients are as sharp as offshore gradients, or for zooplankton species which undergo extensive diurnal vertical migration. In upwelling regions, the cross-shelf component of flow is strongly depth-dependent, with offshore flow limited to a rather thin surface layer; the compensating onshore flow may occur along the bottom as it appears to off northwest Africa (Mittelstaedt, Pillsbury and Smith, 1975) or in the interior as it does off Oregon (Huyer, 1976). Thus lateral advection of a migrating organism would depend upon the vertical structure of the currents. The upwelling circulation off Peru was generally three-layered: The surface offshoce flow was confined to roughly the upper $20 \mathrm{~m}$, the compensating onshore flow was maximum at middepth (about $60 \mathrm{~m}$ at $\mathrm{C}-3$ ) and there was very weak offshore flow along the 
bottom (Brink, Allen and Smith, 1978). Even though an upwelling circulation did not dominate the cross-shelf currents during the period of our study, there was significant vertical structure in the cross-shelf currents (Figure 11) which would subject migrating zooplankton to opposing lateral flows during a daily cycle. Our result that the abundance of zooplanton at $\mathrm{C}-3$ is strongly affected by the near-surface current indicates that there was little or no vertical migration and that the zooplankton were concentrated in the upper layer. The conclusion that there was little vertical migration is consistent with the dominance of Acartia tonsa and the presence of oxygendepleted water below $30 \mathrm{~m}$ : Acartia tonsa seldom exhibits diurnal migratory behavior (Conover, 1956) and the lack of sufficient oxygen probably also inhibits any tendency of other species to migrate downward.

In many coastal upwelling regions, the currents fluctuate with a timescale of several days, while most species of. zooplankton have a life cycle lasting several weeks. The numerical dowinance of Acartia tonsa in this study may be related to the unusual temporal scales for processes affecting A. tonsa. The dominant period of onshore advection was about six days, while that for maximum reproduction and growth of A. tonsa was about thirteen days (llelule, 1966). Thus, the advective time-scale and the time-scale for maximum rates of production for Acartia tonsa are of the same order, suggesting comparable importance for the two processes. The suitability of dinoflagellates as food, observed as ingestion, may be taken to indicate the likelihood of enhanced egg production (Morey-Gaines, 1979). The numerical dominance of A. tonsa was apparently the result of its ability to grow and reproduce rapidly on a diet of dinoflagellates, its tendency not to undergo diurnal vertical migration into deeper oxygen depleted water, and conceivably to a favorable advective regime. 


\section{ACKNOWLEDGMENTS}

This study was supported by the Coastal Upwelling Ecosystems Analysis Program of the Office for the International Decade of Ocean Exploration of the National Science Foundation (NSF Grants OCE 78-03380, OCE 78-03381, OCE 78-05737-AOI 'and OCE 78-03043), and by the Instituto del Mar del Peru. Robert L. Smith provided the 1976 current meter data, and David Stuart provided data on winds. Susan A. Huntsman and Dolors Blasco participated in early discussions of data which led to this paper. 
Figure 1. Location of zooplankton observations from R/V Alpha. Helix, 28 March - 11 April 1976. C-3 is the location of the daily time series. Currents were measured at 10 and $29 \mathrm{~m}$ at Agave $(\Delta)$ and at 28,53 and $78 \mathrm{~m}$ at Mila ( 0 ). The wind was measured at a coastal station at Punta San Juan.

Figure 2. Settled volume and biomass of the zooplankton at c-3, crossshelf current at Agave and wind at San Juan. Settled volume is shown for 50 and $100 \mathrm{~m}$ net hauls of the $300 \mu \mathrm{m}$ Hensen net; biomass as dry weight is shown for $100 \mathrm{~m}$ hauls of both $102 \mu \mathrm{m}$ Bongo net and the 300 um Hensen net. The cross-shelf current at $10 \mathrm{~m}$ Agave is shown (-) with its time integral (-) depicting displacement of a water mass from its position on 3 April if the currents were homogeneous in space.

Figure 3. Vertical profile of the concentration of dissolved oxygen at C-3, from Alpha-Helix stations $20,22,24,27-29,31$ and 33, made daily 3 April to 11 April 1976. Values were determined with a polarographic oxygen electrode (MacIsaac et a1., 1979).

Figure 4. The offshore distribution of biomass collected in vertical hauls of the $300 \mu \mathrm{m}$ Hensen and $102 \mu \mathrm{m}$ Bongo nets between 1 and 5 April, 1976. All hauls except the Hensen net haul at $110 \mathrm{~km}$ offshore were made during daylight. Within $5 \mathrm{~km}$ of shore, net hauls were made to $50 \mathrm{~km}$; between 5 and $25 \mathrm{~km}$, net hauls were made to $100 \mathrm{~m}$; farther offshore, net hauls were made to $200 \mathrm{~m}$. 
Figure 5. Time-series of the observed and "predicted" biomass at c-3 for the $102 \mu \mathrm{m}$ Bongo net and the $300 \mu \mathrm{m}$ Hensen net. "Predicted" biomass is computed from the onshore (positive) or offshore (negative) displacement of the offshore profile of biomass from 1ts assumed position of 3 April (Figure 4).

Figure 6. Offshore profiles of abundance of varlous species of zooplankton in the oceanic group, the continental slope group and the continental shelf group. Note the change of scale from one group to another. All abundances are from hauls of the $300 \mu$ m Hensen net from $50 \mathrm{~m}$ to the surface, except at $77 \mathrm{~km}$ from shore where the 50 m sample was lost and we used the 200 m hanl.

Figure 7. Time-series of the abundance of various species of zooplankton in the continental shelf, continental slope and oceanic groups, with the cross-shelf component of the current at $10 \mathrm{~m}$ Agave (-) and its time integral(--). All abundances are from the $50 \mathrm{~m}$ haul of the Hensen net.

Figure 8. Time-series of the observed and "predicted" abundance at C-3 of Paracalanus parvus, Centropages brachiatus, and Acartia tonsa. Data are from $50 \mathrm{~m}$ hauls of the Hensen net.

Figure 9. Observed and calculated percentages of the number of nauplii and copepodids in the Acartia tonsa population at $\mathrm{C}-3$. The dashed lines were calculated from the maximum growth rates for $\underline{A}$. tonsa obtained by Heinle (1966).

Figure 10. Ingestion rates of Acartia tonsa feeding on phytoplankton assemblages containing 25-50\% diatoms, 50-75\% diatoms, and 75-90\% diatoms. Data are from grazing experiments conducted on the Alpha Helix during 22-28 April 1976. 
Figure 11. Observed midshelf, onshore (positive) and offshore (negative) flow at C-3, 28 March - 11 April 1976. Data are from $10 \mathrm{~m}$ at Agave and 28, 53, and $78 \mathrm{~m}$ at Mila. 


\section{LITERATURE CITED}

Boyd, C.M., S.L. Smlth, and T.J. Cowles. 1979. Grazing patterns of copepods in the upwelling system off Peru. Limnol. Oceanogr., in press. Brink, K.H., J.S. Allen and R.L. Smith. 1978. A study of lowfrequency fluctuations near the Peru coast. J. Phys. Oceanog., $8(6): 1025-1041$.

Brink, K.H., R.L. Smith and D. Halpern. 1978. A compendium of time series measurements from moored instrumentation during the MAM 17 phase of JOINT-II. School of Oceanography, Oregon State University. CUEA Tech. Report 45, Ref. 78-17, 72 pp.

Conover, R.J. 1956. Oceanography of Long Island Sound. VI. Biology of Acartia clausi and A. tonsa. Bull. Bingham oceanogr. Coll. 15: 156-233.

Cowles, T.J. Copepod feeding in the Peru upwelliug system.. Ph.D. dissertation, Duke University; Durham. 173 pp.

Dugdale, R.C., J.J. Goering, R.T. Barber, R.L. Smith and T.T. Packard. Denitrification and hydrogen sulfide in the Peru upwelling region during 1976. Deep-Sea Res. 24: 601-608.

Enfield, D.B., R.L. Smith and A. Huyer. 1978. A compilation of observations from moored current meters, Volume XII: wind, currents and temperature over the continental shelf and slope off Peru during JOINT-II, March 1976 - May 1977. School of Oceanography, Oregon State University, Data Report 70, Ref. 78-4, 343 pp.

Frost, B.W. 1972. Effects of size and concentration of food particles on the feeding behavior of the marine planktonic copepod Calanus pacificus. Limnol. Oceanogr. 17: 805-815. 
Heinle, D.R. 1966. Production of calanoid copepod, Acartia tonsa, in the Patuxent River estuary. Ches. Sci. 7 : 59-74.

Heinrich, A.K. 1973. Horizontal distribution of copepods in the Peru Current region. Oceanology 13: 94-103.

Huyer, A. 1976. A comparison of upwelling events in two locations: Oregon and northwest Africa. J. Mar. Res. 34:531-546.

Longhurst, A.R. 1967. Vertical distribution of zooplankton in relation to eastern Pacific oxygen minimum. Deep-Sea Res. 14: 51-63.

MacIssac, J.J., J.E. Kogelschatz, B.H. Jones, Jr., J.C. Paul, N.S. Breitner, and N. Garfield, eds. 1979. JOINT-II R/V Alpha Helix Productivity and Hydrographic Data, March-May 1976. Data Report No. 48, C.U.E.A., $324 \mathrm{pp}$.

Mittelstaedt, E., R. D. Pillsbury, and R. L. Smith. 1975. Flow patterns in the northwest African upwelling area. Dtsch. Hydrogr. Z. 28:145-167. Morey-Gaines, G. 1979. The ecological role of red tides in the Los Angeles-Long Beach harbor food web. IN: Taylor and Seliger, eds. Toxic Dinoflagellate Blooms, Elsevier North Holland, Inc. pp. 315-320. Packard, T.T., R.C. Dugdale, J.J. Goering and R.T. Barber. 1978. Nitrate redurtase artivity in the suhsurface waters of the Peru rurrent. I. Mar. Res., 36(1):59-76.

Peterson, W.T., C.B. Miller, and A. Hutchinson, 1979. Zonation and maintenance of copepod populations in the Oregon upwelling zone. Deep-Sea Res., 26:467-494.

Rojas de Mendiola, B. 1979. Red tide along the Peruvian coast. IN: Taylor and Seliger, eds. Toxic Dinoflagellate Blooms, Elsevier, North Holland, Inc. pp. 183-190. 
Seki, H., T. Tsuji and A. Hattori. 1974. Effect of zooplankton grazing on the formation of the anoxic layer in Tokyo Bay. Estuar. cstl. mar. Sci. $2: 145-151$.

Smith, R.L. 1978. Poleward propagating perturbations in currents and sea levels along the Peru coast. J. Geophys. Res., 83:6083-6092.

Smith, S.L. 1978. Nutrient regeneration by zooplankton during a red tide off Peru, with notes on biomass and species composition of zooplankton. Mar. Bio1. 49: 125-132.

Stuart, D.W., M.A. Spetseris and M.M. Nanney. 1976. Meteorological data JOINT -II: March, April, May 1976. CUEA Data Report 34. Florida State University, Dept. of Meteorology. Ref FSU-CUEA-MET 76-2.

Vidal, J. 1968. Copepodos calanoideos epipelagicos de la expedicion Marchile II. Gayana 15: 1-98.

Walsh, J.J., J.C. Kelley, T.E. Whitledge, J.J. MacIsaac, and S.A. Huntsman. 1974. Spin-up of the Baja California ecosystem. Limnol. Oceanogr. 19: 553-572.

Walsh, J.J. 1978. The biological consequences of interaction of the climatic, El Nino, and event scales of variability in the eastern tropical Pacific. Rapp. P.-v. Reun. int. Explor. Mer 173: 182-192. 


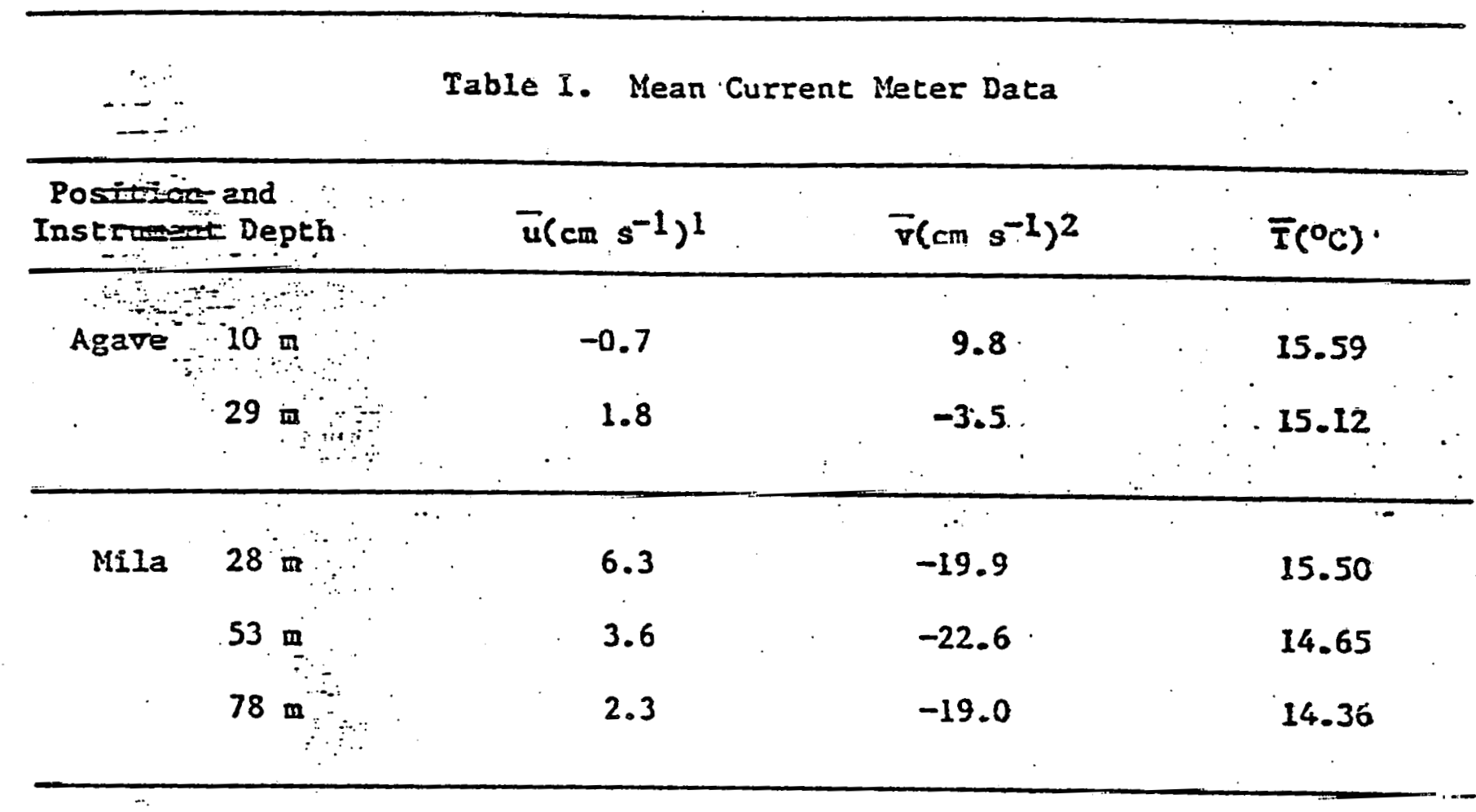

1Positive (negative) values are for onshore (offshore) flow.

${ }^{2}$ Positive (negative values) are for equatorward (poleward) Flon. 


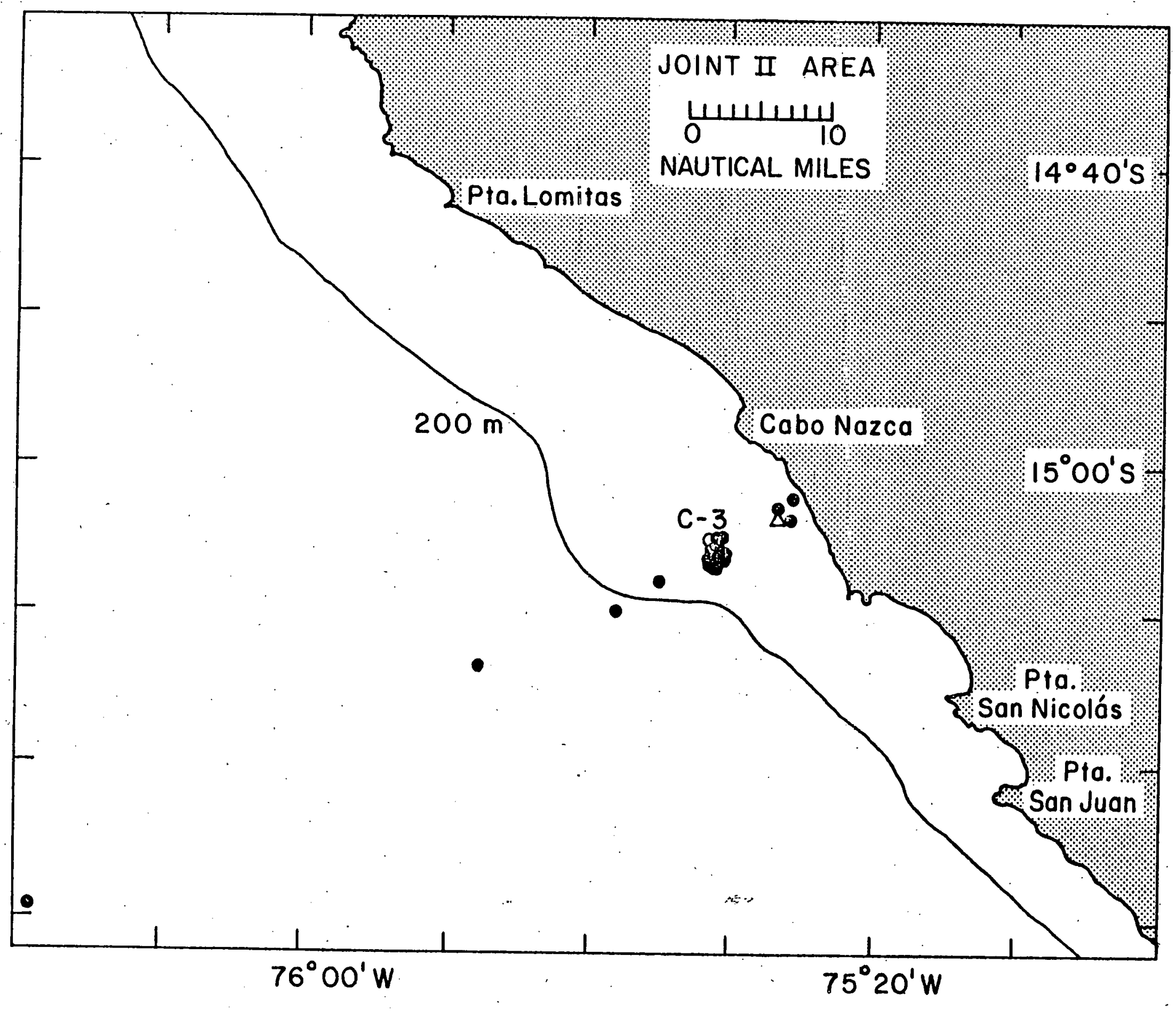



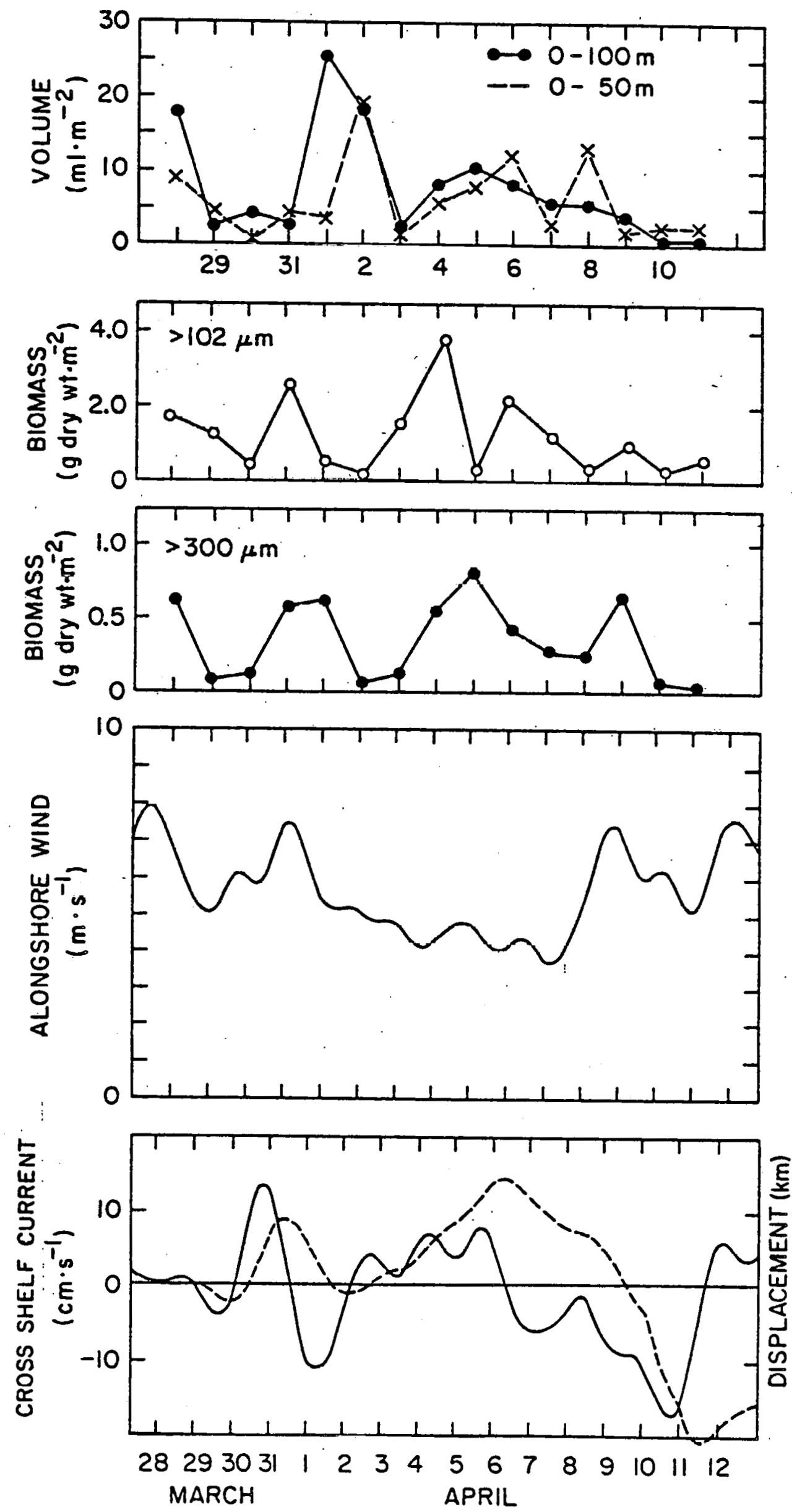


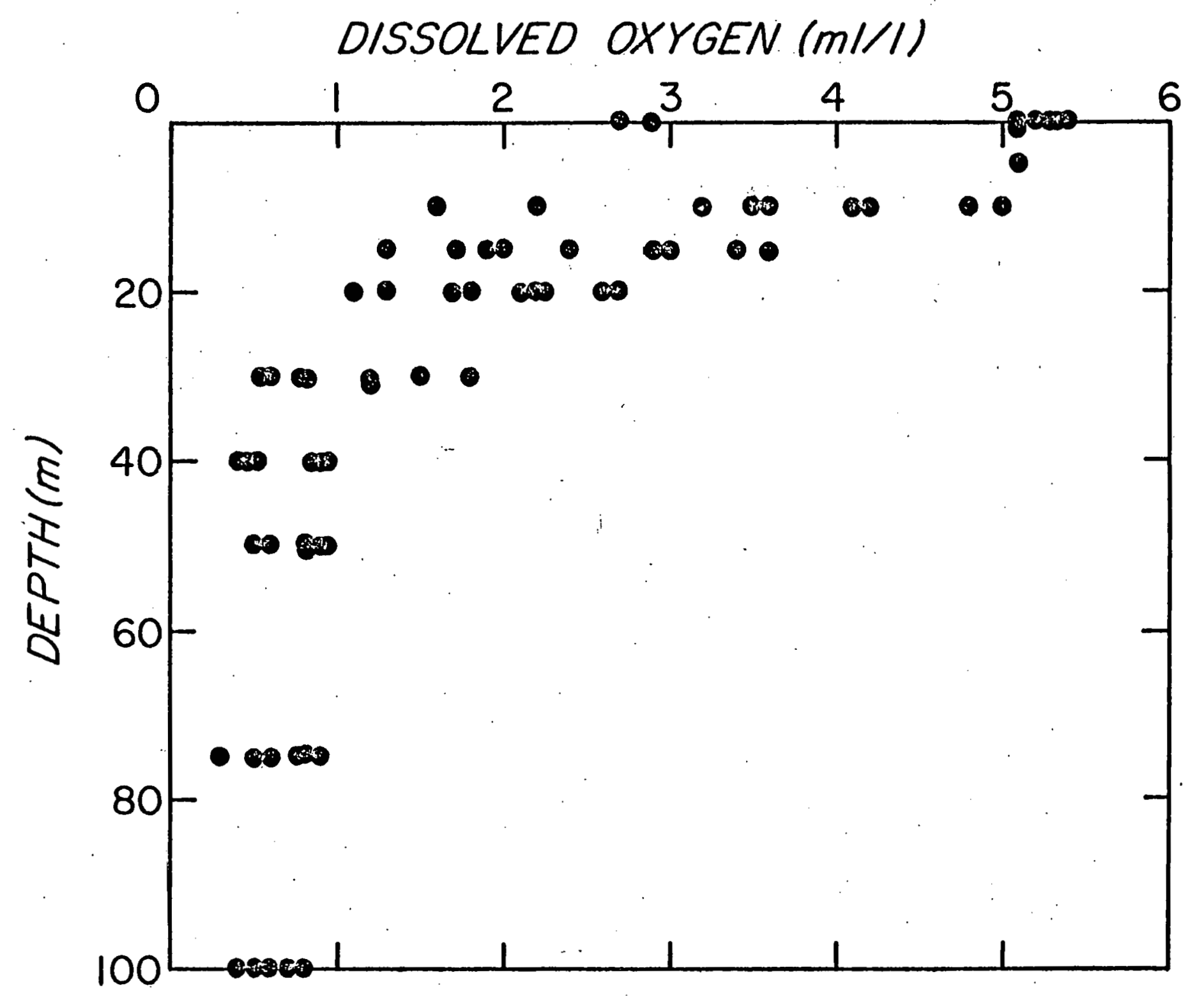

$\sin 4$ it 


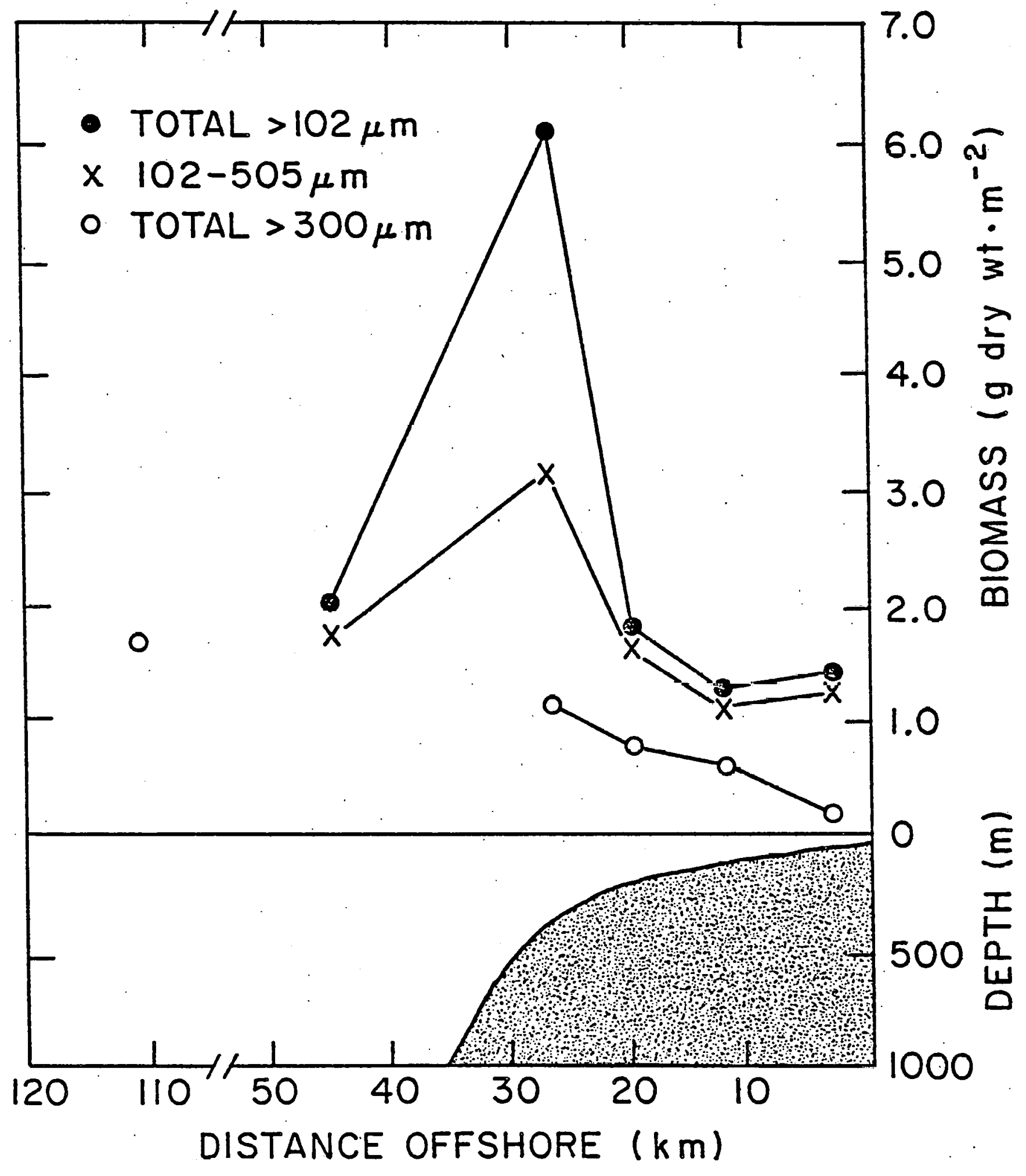

J II 76 


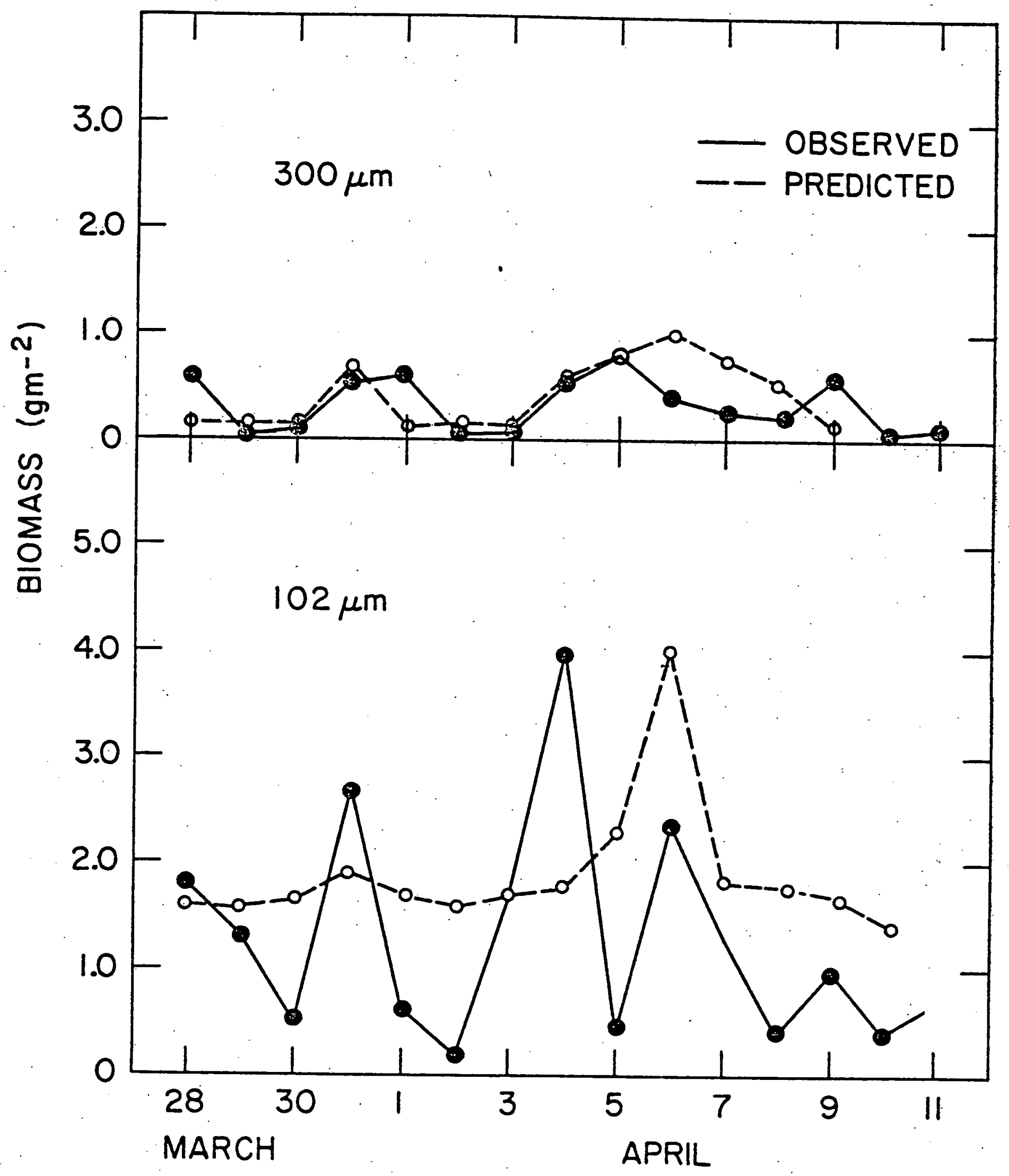

Smits!n!
$+1 g^{\prime}=$ 


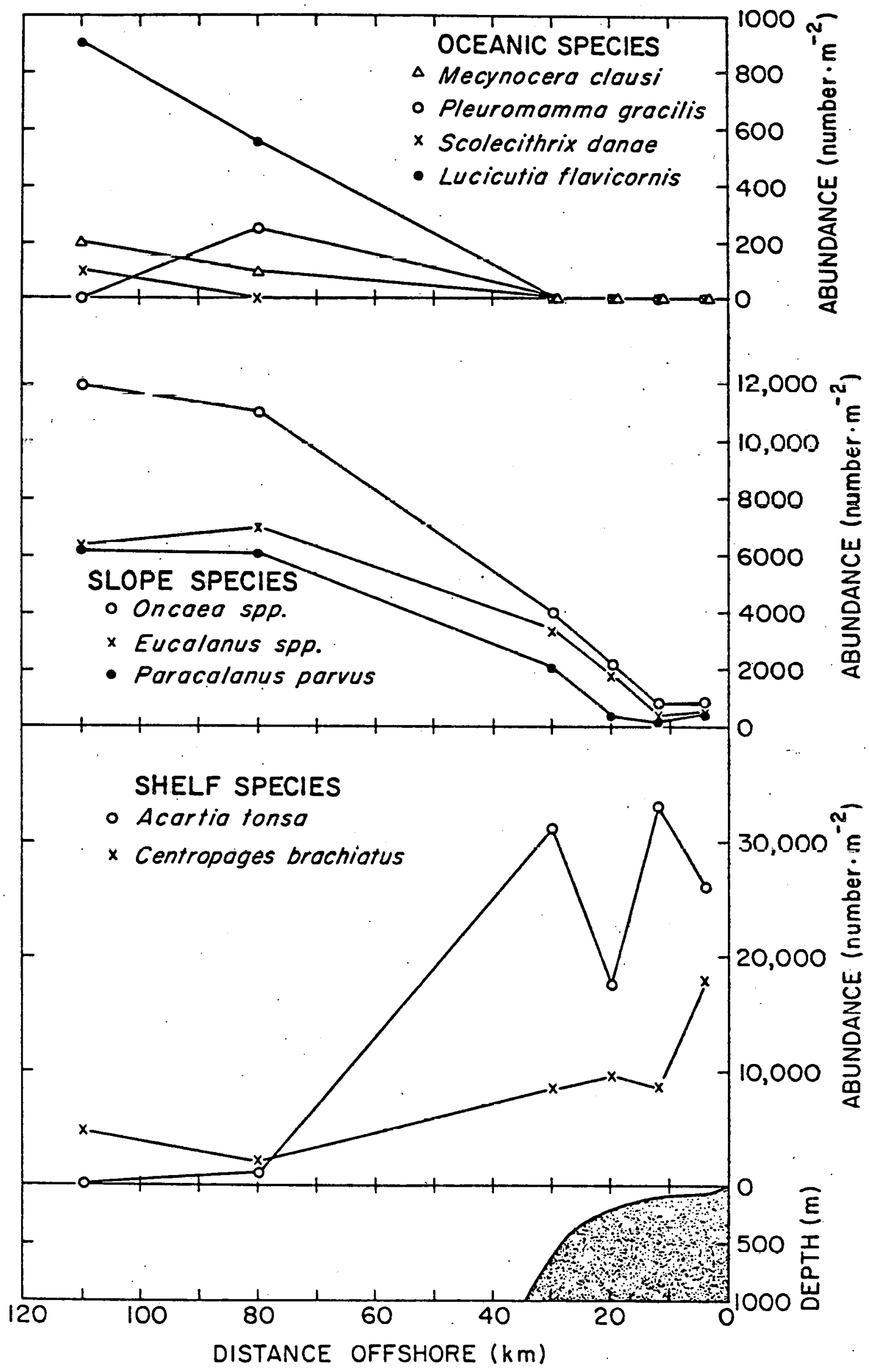



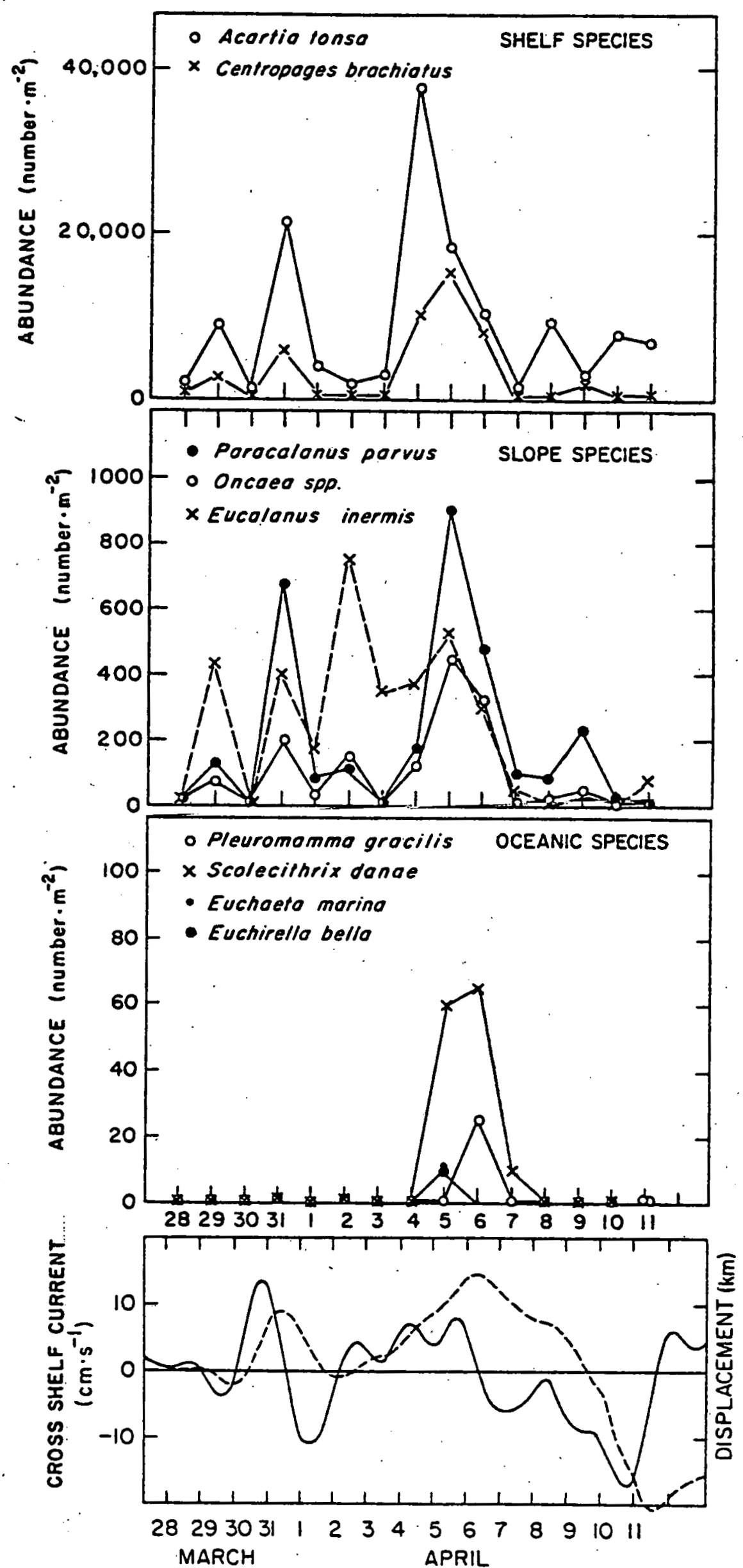

Smanchai. $x 9^{2}$ 

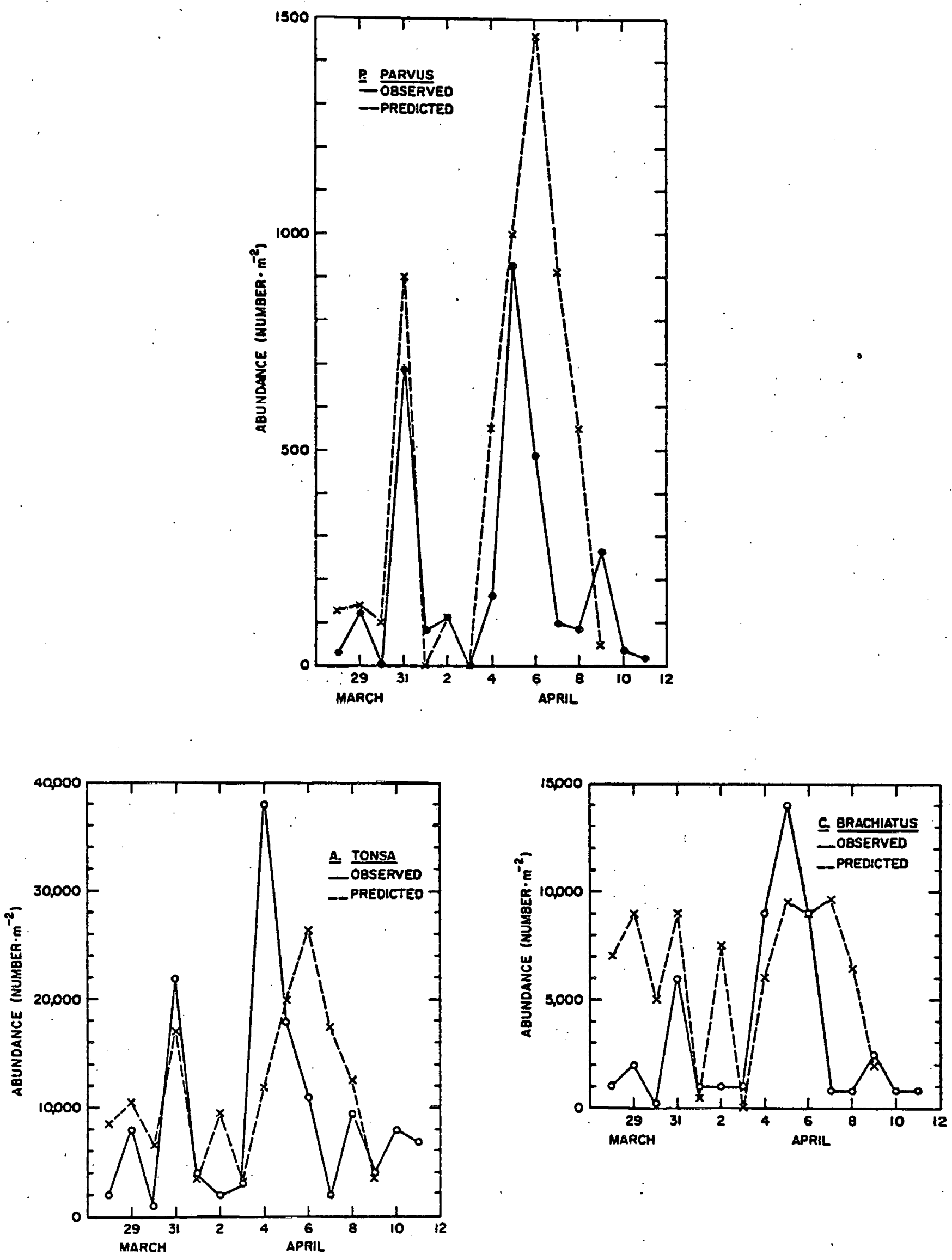


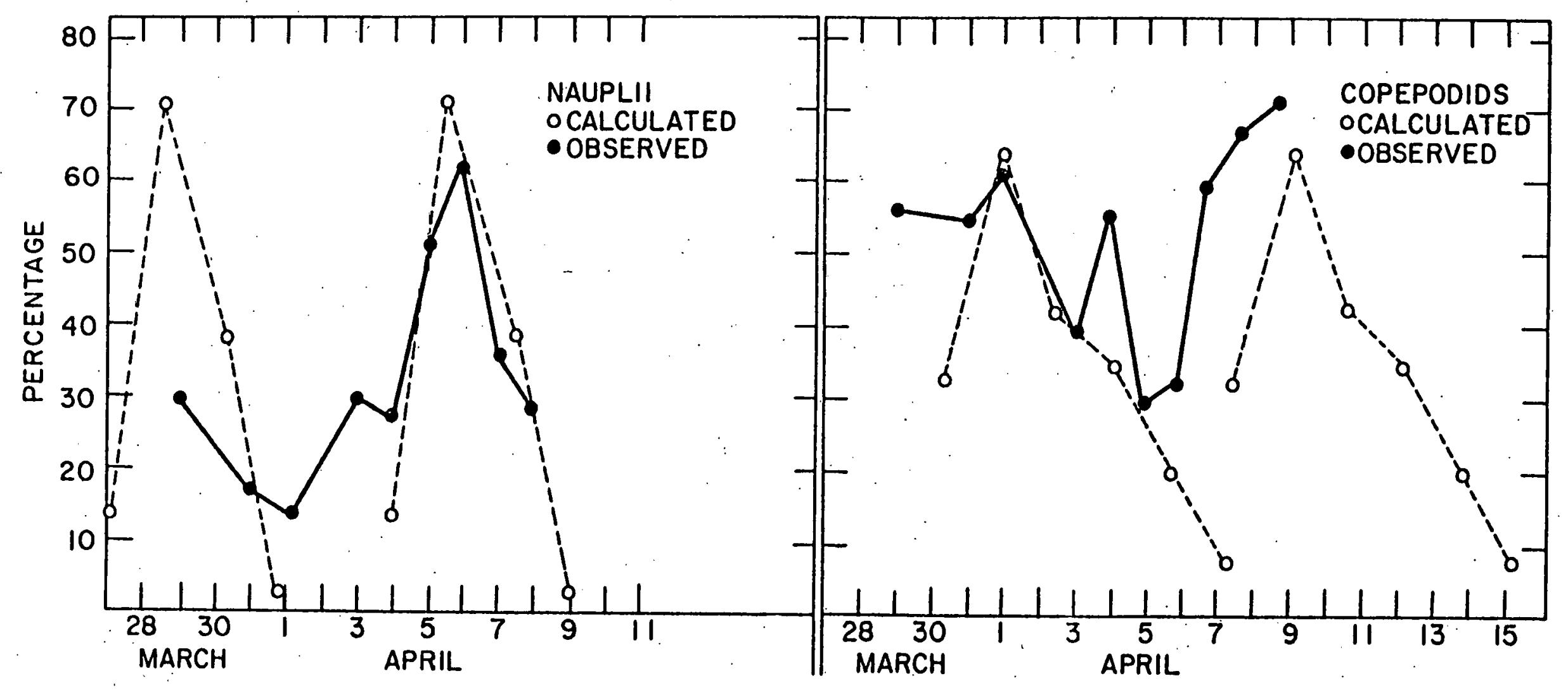

$\stackrel{5}{B}=$ 


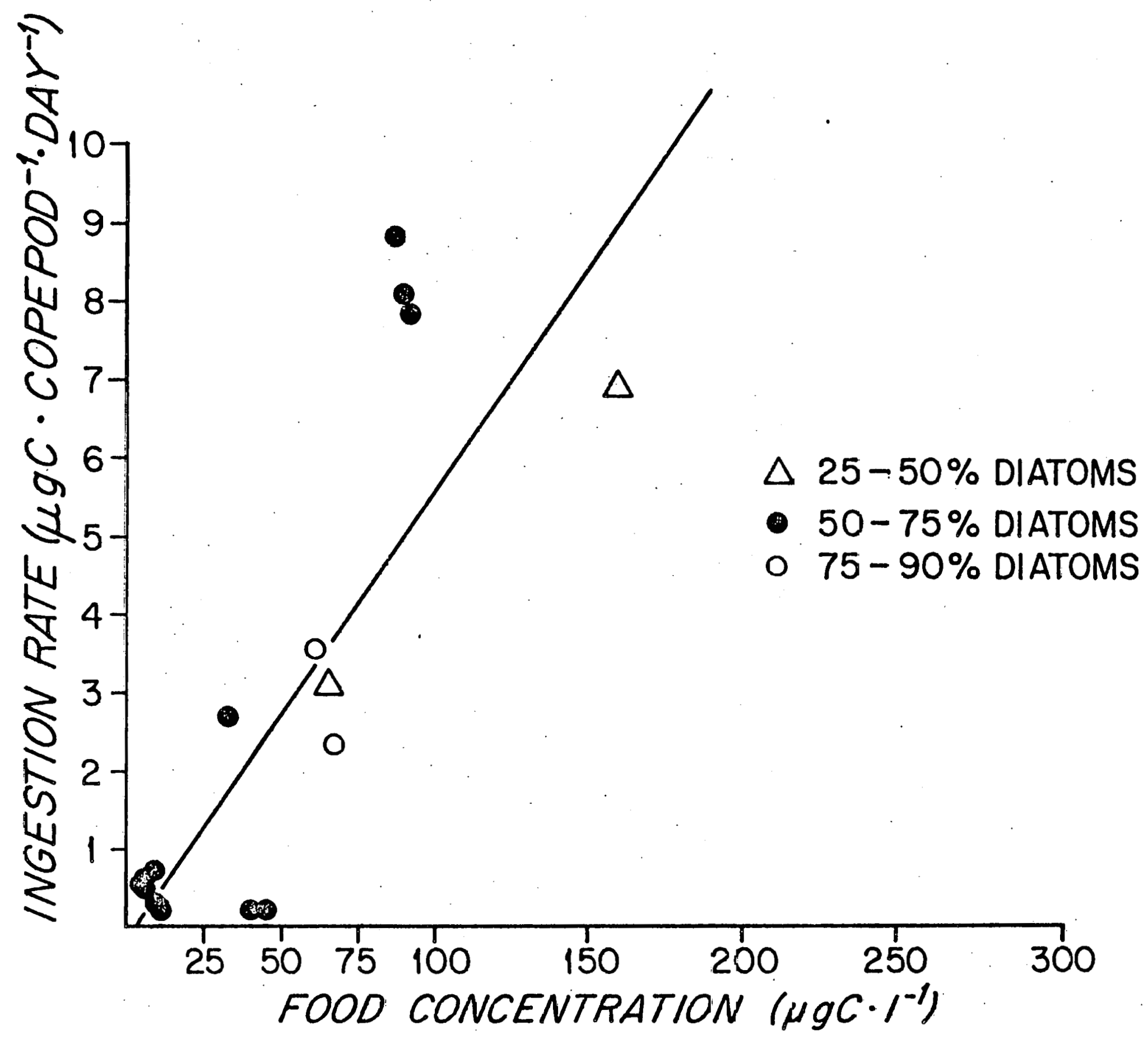




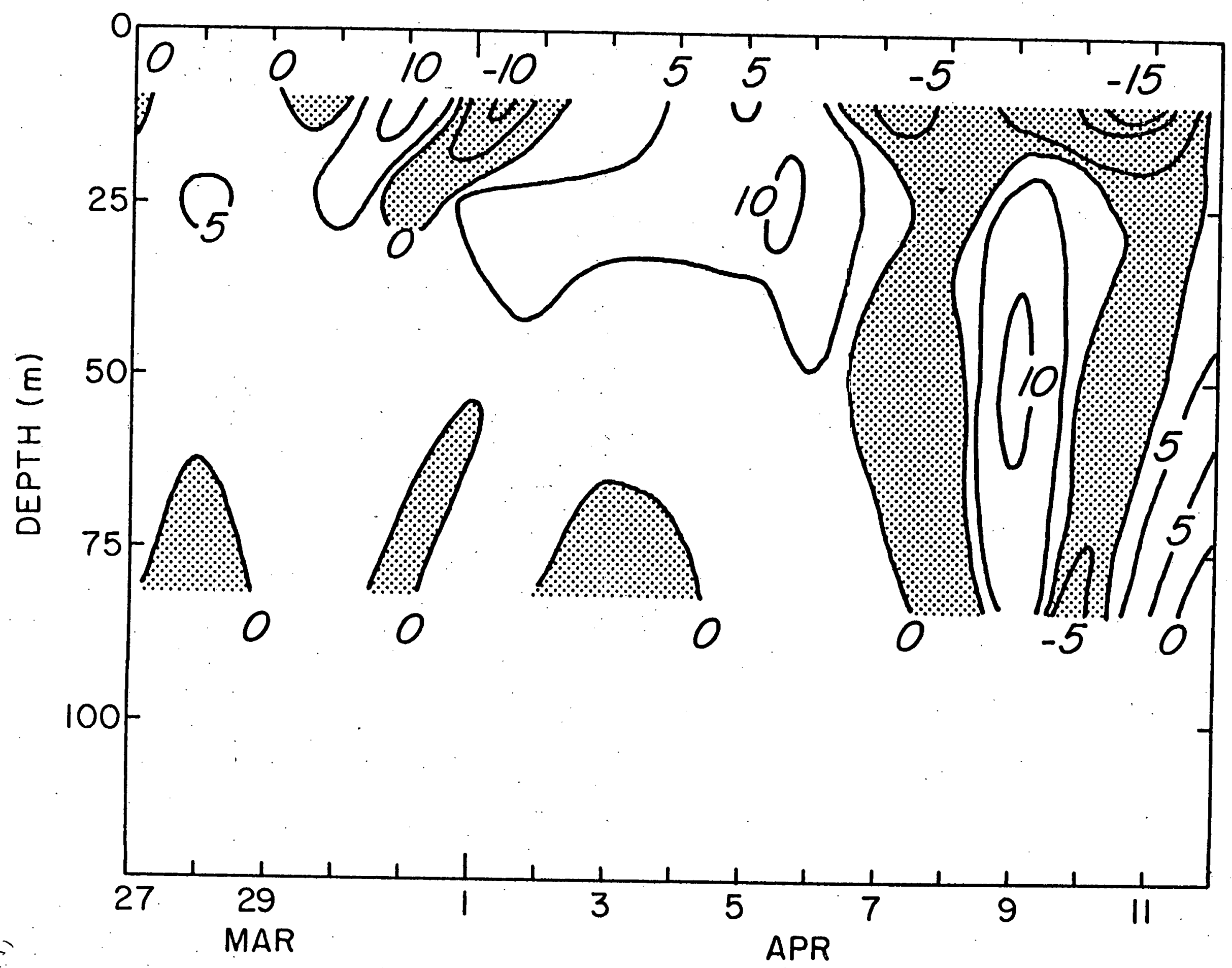

